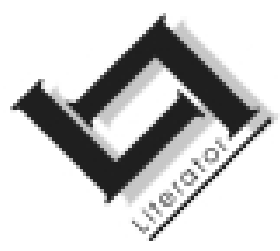

\title{
Translating traces: Deconstruction and the practice of translation
}

\author{
J.L. Kruger \\ School of Languages \\ Vaal Triangle Campus \\ North-West University \\ VANDERBIJLPARK \\ E-mail: engjlk@puk.ac.za
}

\begin{abstract}
Translating traces: Deconstruction and the practice of translation

In this article I attempt to show that deconstruction and its practices should not be read as intimations towards plurality or relativism in translation, but should rather be utilised as a powerful analytical tool, a way of reading and writing with heightened awareness. In order to arrive at this conclusion, I discuss différance and the play of the trace in the context of the cont(r)act between two texts that are in a relationship of translation. I further argue that plurality as contained in Derrida's différance is not a directive, but that the translator has to be aware of the existence of plurality and to take into account that the reader also participates in and contributes to this plurality.
\end{abstract}

The key to an application of Derrida's theory is shown to be situated in the process rather than in the product of translation, and this process has to move beyond a hierarchical opposition of "original" and translation. I conclude that différance becomes not an obstacle or barrier to translation, but specifically that which, in making something untranslatable, creates the need for translation.

\section{Opsomming}

Die vertaling van spore: dekonstruksie en die praktyk van vertaling In hierdie artikel poog ek om te toon dat dekonstruksie en die gebruike daarvan nie gesien moet word as 'n oproep tot veelvoudige interpretasie of relativisme in vertaling nie, maar dat dit eerder ingespan moet word as 'n kragtige analitiese vaardigheid; 'n manier van lees en skryf met verdiepte aandag. Om tot hierdie gevolgtrekking te kom bespreek ek différance en die spel van spore in die konteks van die kont(r)ak tussen twee tekste wat in 'n verhouding van vertaling tot 
mekaar staan. Verder voer ek aan dat veelvoudigheid soos vervat in Derrida se différance, nie 'n voorskrif is nie, maar dat die vertaler bewus moet wees van die bestaan van veelvuldigheid en in ag behoort te neem dat die leser ook deelneem aan en bydra tot hierdie veelvuldigheid.

Die sleutel tot die toepassing van Derrida se teorie is gesetel in die proses eerder as die produk van vertaling, en hierdie proses moet verder gaan as die hiërargiese teenstelling van "oorspronklike" en vertaling. Ek kom tot die slotsom dat différance nie 'n struikelblok vir vertaling is nie, maar dat dit eerder die behoefte vir vertaling daarstel deur onvertaalbaarheid te identifiseer.

\section{Introduction}

The primary aim of this article is to investigate the possibilities offered by deconstruction, and particularly the contributions of Jacques Derrida, for the practice of translation. Like Kathleen Davis's Deconstruction and translation (2001), this article will focus primarily on Derrida's contributions since Derrida is the one "who coined the term 'deconstruction' and who produced (and continues to produce) most of what have become its primary texts" (Davis, 2001:1). In addition, the importance of Derrida's other term, différance, to translation theory provides a useful angle into this selfquestioning discourse.

Deconstruction destabilises a number of "safe" conceptions associated with translation theory. In the words of Koskinen (1994: 446), "by denying the existence of Truth, origin and center, deconstruction deprives us of the comfortable fallacy of living in a simple and understandable world. We lose security, but we gain endless possibilities, the unlimited play of meanings". 1 What has to be determined, however, is whether deconstruction actually contributes to the practice of translation. Does its questioning of conventional notions (such as equivalence and faithfulness) not render its insights so devastatingly relativist that the practising translator cannot afford to pay it more than a passing and slightly amused glance before returning to the serious task at hand?

The usefulness of deconstruction to the practice of translation has often been questioned due to its essentially philosophical nature. Many translators would probably agree with Anthony Pym (1999)

1 As will be explained later, this does not constitute a call for, or justification of, "free" play - i.e. arbitrary meaning. 
that philosophers (and by implication theorists like Derrida) "have no time for the rubbish that most of us have to improve when we translate". Indeed, contemporary translation theory does seem to be moving towards a more functionalist integration of theory and practice, and in this spirit it is as important not to discard philosophy as it is to remain grounded in the "reality" of translation practice with its improbable deadlines, impossible clients and less-than-perfect source texts.

The main problem deconstruction poses to the practice of translation is its seemingly relativist open-endedness and its plural perspectives on the process of signification. Furthermore, deconstruction affects conventional notions such as equivalence 2 and faithfulness in translation, rendered powerless the moment we question concepts such as "truth", "origin" and "centre". Put simply, deconstruction removes equivalence from the skopos (cf. Vermeer, 2000 [1989]) or purpose of translation. This simple action of elimination, however, has serious consequences for the very identity of translation. As any practising translator knows, equivalence, regardless of how one chooses to define this elusive concept, remains the single most important criterion by which translations are judged.

However, as this article will attempt to show, deconstruction and its practices should not be read as intimations towards plurality or relativism in translation, but should rather be utilised as powerful analytical tools, ways of reading and writing with heightened awareness. After all, good translators are in the first instance good readers, and by virtue of their mediating position in the cont(r)act between text and translation, they have to (at least) be aware of the plethora of gaps and traces in source and target texts as well as source and target languages and cultures. Indeed, it is precisely this power that derives from its acute awareness of context ${ }^{3}$ and subjectivity that makes deconstruction invaluable to the practising translator.

2 Derived from the mathematical term of equivalence, the term is generally taken to mean that the translation as derivative text is equal in value to, or does not deviate from, the origin(al) as prior text. Equivalence will be defined more clearly under paragraph 3.

3 According to Derrida (1974:158), "there is nothing outside the text", which is interpreted by Davis (2001:9) as making the point that "meaning cannot be extracted from, and cannot exist before or outside of a specific context". 


\section{Jacques Derrida and translation theory}

Derrida has been writing on translation directly or indirectly for most of the latter part of the twentieth century. Although, according to Davis (2001:9), "all of Derrida's texts concern translation in various ways", he addresses translation perhaps more directly in texts such as Des tours de Babel (Derrida, 1985a), The ear of the other: Otobiography, transference, translation (Derrida, 1985b), and, more recently, What is a "relevant" translation? (Derrida, 2001).

Derrida's contribution to translation theory is located primarily in his reclaiming of the power of the word and everything it has the potential to signify: "At the beginning of translation is the word. Nothing is less innocent, pleonastic and natural, nothing is more historical than this proposition, even if it seems too obvious" (Derrida, 2001:180.) The importance of the word is particularly evident in his notion of différance, which is central to deconstruction, and which will also be shown in this article to impact on the very activity of translation, literary or otherwise. Therefore, before the implications of the questioning of hierarchical oppositions for translation theory can be investigated more fully, we have to take a closer look at the nuances contained in the term différance.

\section{1 Différance}

What is written as différance, then, will be the playing movement that 'produces' - by means of something that is not simply an activity - these differences, these effects of difference. This does not mean that the différance that produces differences is somehow before them, in a simple and unmodified - in-different - present. Différance is the non-full, non-simple, structured and differentiating origin of differences. Thus the name 'origin' no longer suits it (Derrida, 1982:11).

Derrida's perspectives on translation are closely related to his definition of différance. The process by which différance is approached and by which it approaches becomes the process by which words and translation are approached and approach; not in terms of what these words and processes signify, but in terms of what they activate or "produce" by means of "the playing movement" through both temporal and spatial dimensions. The very activity of translation cannot be separated from this difference between signifier and signified and becomes part of the existence and production of the inevitable tension. 
In 1968 Derrida defined différance in an address before the Société Française de Philosophie, subsequently published in Margins of philosophy (1982). He began the address with the sentence, "I will speak, therefore, of a letter" (Derrida, 1982:3). This already signals that the significance of différance is situated in one letter that erases the trace of what would otherwise have been a "word" or a "concept" but which Derrida (1982:7) insists is neither.

Différance is based on the French verb différer (from the Latin verb differre). This verb has two distinct meanings in French which are represented by two separate words in English, namely to differ and to defer. 4 The first and more common sense of the verb brought to différance, namely to differ, is related to a spatial horizon or spacing, which implies "to be not identical, to be other, discernible, etc." and also refers both to different things and differences of opinion (Derrida, 1982:8). The second sense of the verb, namely to defer, is in turn related to a temporal horizon or temporisation by which term Derrida (1982:8) summarises concepts such as "the action of putting off until later, of taking into account, of taking account of time and of the forces of an operation that implies an economical calculation, a detour, a delay, a relay, a reserve, a representation". It also implies "to temporize, to take recourse, consciously or unconsciously, in the temporal and temporizing mediation of a detour that suspends the accomplishment or fulfillment of 'desire' or 'will,' and equally effects this suspension in a mode that annuls or tempers its own effect" (Derrida, 1982:8).

Therefore, Gentzler's (1993:158-159) statement that différance refers "not to what is there (language), but what is not there, and thus calls into question any ontological approach that attempts to determine a notion of Being based on presence" sums up the significance of this not-word, not-concept for translation. Translation now becomes a transformation of potential instead of a passive transfer of meaning or ontological presence. In the words of Davis (2001:14), meaning "is an effect of language, not a prior presence merely expressed in language. It therefore cannot be simply extracted from language and transferred".

$4 \quad$ The fact that the dual meaning in French is therefore untranslatable in English in spite of the proximity of the words, emphasises exactly what différance attempts to capture, namely that which cannot be named. Even a similar attempt like defference fails to activate similar traces in English. 
Différance is not - it contains its own death in the trace of spatial difference (it can never "be" present), as well as its sur-vival in the trace of temporal deferral (it is always "becoming" present). It constitutes a silent error that disappears as it is spoken, leaving a trace that can never be present. Reference becomes extremely important here in that the "middle voice", as well as the notion of something that is absent, transcends the "here and now" but also the "there and then", creating a space that is simultaneously impossible to ignore and impossible to account for. Although the formalist concept of defamiliarisation or Verfremdung is still present in the term (involving as it does the abstract recreation and revoicing of silenced modes), the unnameable also creates a palimpsest that affects/effects presence through absence. Différance hints at presence without providing that which would make it possible to inscribe or infer presence. 5

\section{Begam (1992:876) points out that différance moves}

... along two essentially opposed trajectories of meaning: on the one hand, it gestures towards presence or self-identity ... on the other hand, it gestures toward absence or difference ... This means that to think différance is to think what is simultaneously same and other, what is simultaneously itself and its opposite.

Or, in the words of Derrida (1982:9), "the sign represents the presence in its absence. It takes the place of the present ... The sign, in this sense, is deferred presence". This aspect of différance is of particular importance to translation theory, since it touches on the essence of translation and the relation between "original" and "translation". Since translation deals with a representation of this representation of the sign, presence remains deferred in the translating text or rewriting just as it is deferred in the "original". After all, translation also deals with the traces left by the presence, but always in absence and never with a fixed meaning that can be transferred between languages (as traditional theories would sometimes have it).

5 Without elaborating on the point needlessly, it is important to note that Derrida does not deny the referential effect of language, but rather implies that the potential presence of the signified ("referent") has no effect on the structure of the signifier ("mark"). In the words of Clarkson (2003:38), "the referential effect can take place precisely because the sign (mark) is constructed on the basis that it is able to endure the absence of the referent, and still do the job". 
Derrida (1982:25-26) deconstructs différance as follows:

There is no essence of différance; it is that which not only could never be appropriated in the as such of its name or its appearing, but also that which threatens the authority of the as such in general, of the presence of the thing itself in its essence. That there is not a proper essence of différance at this point, implies that there is neither a Being nor truth of the play of writing such as it engages différance.

In these words the full impact of différance becomes evident. It remains indefinable because of a continual differing and deferring and at the same time it posits that there can be no such thing as Being precisely because of this play of differences. Davis (2001:15) points out that 'Derrida's use of the word 'play' in this context is often misunderstood, most grievously when taken as an argument for complete 'freeplay' in language: that is, the suggestion that a signifier can ultimately mean just anything at all". In approaching translation or translation theory we have to take cognisance of the unnameable, but we also have to be aware of the play constituted by gaps that allow movement. However, as will be shown in the following section, this very fact not only makes translation as rewriting possible, but also renders it essential as process if not as product.

\subsection{Gaps and traces}

A translation is never quite 'faithful', always somewhat 'free', it never establishes an identity, always a lack and a supplement, and it can never be a transparent representation, only an interpretive transformation that exposes multiple and divided meanings, equally multiple and divided. (Venuti, 1992:8; my emphases - JLK.)

Through the inevitable existence of gaps and traces in any text, translation exposes and uncovers, but also establishes lacks and supplements. Derrida's project, according to Gentzler (1993:160), "is one of trying to unveil ... a play of covered-up but subconsciously discernible traces without referring to some sort of deep underlying meaning". According to Davis (2001:15), "Derrida usually speaks of the trace, rather than the signifier, partly to recall its sense of a 'track' or even a 'spoor'”.

As a result of the play of differences, any text becomes a footprint that contains in it traces of the past and future, but that can never be 
pinned to an "essence" or "fixed meaning". "It is because of différance," Derrida (1982:13) maintains,

... that the movement of signification is possible only if each socalled 'present' element, each element appearing on the scene of presence, is related to something other than itself, thereby keeping within itself the mark of its past element, and already letting itself be vitiated by the mark of its relation to the future element, this trace being related no less to what is called the future than to what is called the past, and constituting what is called the present by means of this very relation to what it is not: what it absolutely is not, not even a past or a future as a modified present (my emphases - JLK).

Furthermore, Derrida (1982:21) cautions that "the concept of the trace is incompatible with the concept of retention of the becomingpast of what has been present. One cannot think the trace - and therefore, différance - on the basis of the present, or the presence of the present". According to Davis (2001:15), "[t]hese relations to past and future are often called retentive and protentive characteristics, and the trace is where the retentive/protentive relationship with the other is marked".

It is important to note that Derrida does not deny the importance of the truth of Being. In fact, he regards the passage through the truth of Being as remaining an "incessant necessity" (Derrida, 1982:22). However, it remains a "passage through", leading Derrida (1982:23) to define the trace further by stating: "Always differing and deferring, the trace is never as it is in the presentation of itself. 6 It erases itself in presenting itself, muffles itself in resonating, inscribing its pyramid in différance."

Derrida suggests that one should not look at the original message or its codification, "but the multiple forms and interconnections through which it must pass in order to speak, to refer at all", a process which entails what he terms "a play of traces" (Derrida, 1982:15). By extension, according to Gentzler (1993:160), "one could also project a translation theory aimed at protecting differences, reinvigorating

6 In this as well as in the rest of Derrida's explication of trace, we have to bear in mind that "trace" is both verb and noun, and at the same time neither, just as it is neither active nor passive, yet both. 
language with lost etymological resonances, thereby opening up new avenues of thought". 7

This action of "opening up" or "gapping" is central to Derrida's "notion" of différance. In the words of Leonard Cohen (1992) in his song, 'Anthem', "There are cracks, / there are cracks in everything. / That's how the light gets in". The boundary between texts in a contract of translation is also the opening that allows the traces to evoke meaning 'effects' through the play of differences (see also Davis, 2001:30).

Although the above focus on différance and its gaps and traces may already point to the potential of deconstruction in translation, the deconstructionist notion of untranslatability still seems to go directly against the practice of translation. If we remove equivalence from the translation brief, where is the sense in translating? Why would anyone want to pay a translator for a piece of work that offers no clarity, no final answers? After all, untranslatability seems to imply that equivalence is impossible and also that the "original" is untouchable. In order to attempt to address these questions, this article will now turn to the origins of the concept of equivalence as well as the status of the translation before attempting to cross the seemingly insurmountable hurdle of untranslatability.

\section{Equivalence, status and untranslatability}

\subsection{Equivalence}

The history of translation theory can in fact be imagined as a set of changing relationships between the relative autonomy of the translated text, or the translator's actions, and two other concepts: equivalence and function. (Venuti, 2000:5; my emphases - JLK.)

Translation theory over the centuries has been concerned primarily with interlingual translation (in Jakobson's sense; 2000 [1959]:114), in other words the translation of a text from one linguistic system into another. It is therefore not surprising that some notion of equivalence informs most translation theories up to the 1980s, and still does in many ways. Gentzler (1993:144) distinguishes between

7 See Venuti's (2000) notion of "foreignizing", Lewis's (2000 [1985]) notion of abusive translation (derived from Derrida), and Berman's (2000 [1985]) trial of the foreign. In each of these authors' work the impact of the play of traces on translation can be seen in some form or another. 
various forms of equivalence with different emphases, for example the notions of linguistic structural/dynamic equivalence in the "science" of translation, corresponding literary function in early Translation Studies, and similar formal correlation governed by social acceptability in the target culture in polysystem theory and the Translation Studies of the eighties. Venuti (2000:5) similarly lists a number of terms that have been associated with equivalence, namely '“accuracy', 'adequacy', 'correctness', 'correspondence', 'fidelity', or 'identity'; [equivalence] is a variable notion of how the translation is connected to the foreign text". In short, according to Pym (2000), debates over equivalence "concern beliefs that some aspect of a source-text unit can equal some aspect of a target-text unit". Indeed, Derrida himself states that "to make legitimate use of the word translation ... in the rigorous sense conferred on it over several centuries by a long and complex history in a given cultural situation ... the translation must be quantitatively equivalent to the original" (Derrida, 2001:180).

The above-mentioned theories and paradigms deal with translation primarily as interlingual translation, thereby legitimising their use of the term "equivalence". However, we cannot afford to view translation in this restrictive manner, in spite of Pym's (2000) call to do so by not being afraid to "distinguish translation from non-translation". Even if translation is functionalist in purpose, the categories of intralingual translation and even intersemiotic translation are activated to some degree, rendering Jakobson's distinctions problematic if taken as discontinuous categories.

This merging of Jakobson's categories of translation is even more expressly true when we deal with texts that rely heavily on gaps, silences and traces such as political, philosophical, and advertising texts and obviously also literary texts. In the translation of narrative fiction, for example, the gaps and traces created in the narration through different narrative levels and focalisations make certain demands in terms of the involvement of the translator (also as reader) in the actualisation of the text that clearly transcend mere interlingual translation. In texts such as these, the translator also has to focus on those interpretative elements of intralingual translation as well as the imaginative elements inherent in intersemiotic translation that exist in both source and target text or, perhaps more appropriately, in both texts that form the contract of translation as rewriting.

The reason for the failure of Jakobson's tripartite division as well as the conventional notion of equivalence when viewed from a 
deconstructionist perspective, can mainly be ascribed to the failure of the limits they attempt to set. 8 The very premise of the category of intralingual translation, for example, is that it is possible to determine the form of the limits of a language. In the words of Davis (2001:20), the limit of a language, "is not 'decidable' or absolute (which would cleanly cut languages off from each other), but a boundary and a structural opening between languages, contexts".

The development of equivalence as a term to describe the relation between source and target text makes perfect sense if we regard translation as some form of transfer between two languages with clear limits. However, Derrida's contribution to the field is part of a "movement" that calls the very notion of transfer into question. The deconstructionist view that signifier and signified are linked, with the result that you cannot change the one without affecting the other, has a significant impact on translation (Koskinen, 1994:448). No longer can translation be viewed as the transfer of a stable signified between two languages. Derrida's preference for the term "regulated transformation" over that of "translation" (Gentzler, 1993:168) is significant here, in that it draws attention to the fact that equivalence as the transfer of "pure signifieds" between two languages is impossible. Or, in Derrida's words, we have to substitute for the notion of translation "a notion of transformation of one language by another, of one text by another" (Derrida, 1981:21; see also Derrida, 1982:14) - not a transfer of one language into another or one text into another - an action that once again presupposes limits rather than boundaries and openings or gaps.

Derrida does not promote a position aimed at removing purpose from translation. Instead, he merely suggests that the play of traces in the source text remains a play of traces in the target text (if not the same trace), and therefore cannot be fixed in a stable signifier. After all, it is impossible to limit or predict the interpretation of a translation by different readers. Furthermore, deconstruction is not only concerned with the analysis of the source text and original meaning, as Pym proclaims, but is also a useful tool for the interpretation of the target text or translation, and Derrida cannot be

8 Of course the division also fails because its sets up a dichotomy between interlingual translation, or "translation proper" on the one hand and intralingual and intersemiotic translation on the other, relegating the latter pair to figural status (Davis, 2001:28). As such, the division privileges interlingual translation in the same way oppositions such as formal/free, original/translation, proper/ improper etc. do. 
accused of being in favour of anything other than meticulous reading of either of these two texts.

The central problem here is that Pym's argument does not sufficiently take into account that Derrida and proponents of deconstruction are not necessarily prescriptive. Rather, according to Venuti (1992:7), "poststructuralist textuality redefines the notion of equivalence in translation by assuming from the outset that the differential plurality in every text precludes a simple correspondence of meaning". Plurality as contained in Derrida's différance is not a directive, nor is it relativistic per se. Deconstruction merely requires the translator to be aware of the existence of plurality and to take into account that the reader also participates in and contributes to this plurality. This makes deconstruction particularly useful in dealing with gaps and traces that exist in both the texts in the translation contract.

Derrida's notion of différance and his pre-occupation with the word have an even more profound impact on translation when we consider translation relevance. In an elaborate argument on the relevance of translation, What is a "relevant" translation? Derrida (2001:181) describes recent "so-called literal translation" as:

a kind of translating that is not word-to-word, certainly, or wordfor-word, but nonetheless stays as close as possible to the equivalence of 'one word by one word' and thereby respects verbal quantity as a quantity of words, each of which is an irreducible body, the indivisible unity of an acoustic form that incorporates or signifies the indivisible unity of a meaning or concept.

Against this background he continues to emphasise the precarious position of the notion of translation:

This is why, whenever several words occur in one or the same acoustic or graphic form, whenever a homophonic or homonymic effect occurs, translation in the strict, traditional, and dominant sense of the term ${ }^{9}$ encounters an insurmountable limit - and the beginning of its end, the figure of its ruin ... A homonym or homophone is never translatable word-to-word. It is necessary either to resign oneself to losing the effect, the economy, the strategy (and this loss can be enormous) or to add a gloss ... Wherever the unity of the word is threatened or

9 In other words, as "transaction and as transfer" (Derrida, 2001:176). 
put into question, it is not only the operation of translation that finds itself compromised; it is also the concept, the definition, and the very axiomatics, the idea of translation that must be reconsidered (Derrida, 2001:181).

This view raises a number of issues that are central to an understanding of Derrida's concern with the word. The above passage emphasises that so-called literal translation deals with words that are significant as words on the basis of their bodies and acoustic form and that each word in turn incorporates and signifies the "indivisible unity of a meaning or concept". In Derrida's view, relevant translation as the transfer of an intact signifier is impossible. Similarly, according to Venuti (2001:171),

... the fact is that any translating replaces the signifiers constituting the foreign text with another signifying chain, trying to fix a signified that can be no more than an interpretation according to the intelligibilities and interests of the receiving language and culture.

Words are therefore not merely incidental signifiers but bring with them a plethora of connotations and voices that are at the same time impossible to translate and essential to translate: "At every moment, translation is as necessary as it is impossible" (Derrida, 2001:183).

Derrida's conception of relevance is directly linked to his notion of translation as economy between property and quantity. What therefore renders equivalence suspect in a Derridean approach is not the fact of a relation obtaining between an "original" or sourcetext unit and a translation or target-text unit, but rather the status of "original" versus translation.

\section{2 "Original" and translation: towards a contract}

In order to exist as meaningful events, texts must carry within themselves traces of previous texts, and are, therefore, acts of citation. The source text for a translation is already a site of multiple meanings and intertextual crossings, and is only accessible through an act of reading that is in itself a translation. The division between 'original' and 'translation', then - as important as it is to translators and translation scholars today - is not something pre-existing that can be discovered or proven, but must be constructed and institutionalized. It is therefore always subject to revision (Davis, 2001:16). 
Translation augments and modifies the original, which, insofar as it is living on, never ceases to be transformed and to grow. It modifies the original even as it also modifies the translating language. This process - transforming the original as well as the translation - is the translation contract between the original and the translating text (Derrida, 1985b:122).

Translation deals with an "original" and a translation insofar as a cont(r)act (i.e. a contract forged by the contact and subsequent continual rewriting) exists between two texts. However, the contract resulting from the contact between the two texts should not be viewed as a dichotomy between two binary opposites, but rather as a continuation, a relationship of mutual transformation, a symbiosis. In describing this cont(r)act, it is nevertheless important to define the relationship that obtains. Translation is more than the mere transformation of an "original". In Derrida's view, the process of translation transforms both "original" and translation and thereby ensures the survival of the "original". However, on the basis of this contract, the boundaries between "original" and translation are obscured as the survival of the "original" becomes intertwined with the survival of the translation. Through the translating text, the translation becomes an "original" itself, in the process also ensuring the survival of language. The palimpsest of the "original" in the body of the translation becomes a play of movement that also engenders a palimpsest in the "original", ensuring a contract through contact in which a symbiosis is established.

This symbiosis obviously extends to all translation and is not limited to the translation of "high literature". In the case of, for example, the translation of the minutes of a meeting, the "original" (or the minutes in the language they were taken down in by the minuting secretary), is in a very real sense intertwined with the translation for the benefit of a member who does not have full access to the "original". Likewise, the "original" in the form of an operating manual for a microwave in, for example, English, is intertwined with the translation of this document into, for example, German or Swahili, since clarifications or factual omissions in the translation will have a direct influence on the act of using the microwave which cannot be removed from the instructions intended by the manufacturer and will therefore have to be reflected in the "original".

Consequently, the violent oppositions or dichotomies that exist in translation theory and require deconstruction, such as word-for-word versus free translation, theory versus practice and "original" versus translated text are all overturned. Furthermore, what Koskinen 
(1994:446) identifies as the most paralysing dichotomy, namely the hierarchical opposition that privileges the "original" and its author above the translation and translator, is rendered powerless and obsolete by this contract.

When we question this hierarchy, the notion of an "original" being inherently untouchable (in that its sanctity will be affected by any rewriting, which will simply violate this sacred text in one way or another), is no longer sustainable. This is the case because any reading of a text changes it and each change triggers subsequent changes, just as any initial choice in a translation influences and determines the rest of the translation. Furthermore, the endless chain of signification (as signified becomes signifier ad infinitum), renders any attempt at closure futile and "meaning-less". Just as there is no transcendental signified for the deconstructionist, there are also "no extralinguistic meanings" (Koskinen, 1994:447). This aspect obviously complicates the process of translation as well as the analysis and description of translations infinitely.

However, the influence of deconstruction on translation does not necessarily have to be regarded as an assault on the integrity of the "original". In the words of Van den Broeck (1988:267), "deconstruction is not an act of destruction, but an act of displacement". The différance that is translation, or that we approach in translation, creates the possibility to approach the hidden, unnamed or unnameable properties in a text without attempting to silence them. This possibility is created through a process of instilling through the translating text a number of gaps or traces that become hidden, unnamed or unnameable without necessarily corresponding with what was hidden, unnamed or unnameable in the "original", but which are informed by the "original" and in turn inform the "original". Just as it is impossible to translate all aspects of any given signifier between the two language systems involved in the translation contract, it is impossible to translate all aspects of the gaps and traces, and new gaps and traces originate in this process just as new chains of signification originate.

But what does this actually mean for translation practice? Does différance render equivalence obsolete in translation? We could perhaps argue that the impossibility of translation - which suggests the impossibility of equivalence - also depends on the possibility of translation and therefore of equivalence for its very existence. Since any theory informed by a notion of equivalence, irrespective of the emphasis, has to distinguish fairly rigidly "between original texts and their translations, distinctions which determine subsequent claims 
about the nature of translation" (Gentzler, 1993:144), equivalence as a transfer between "original" and translation has to be questioned. In this lies the problem of equivalence. In a deconstructionist perspective on translation, equivalence can no longer be regarded as a norm for translation practice, but rather becomes a disappearing trace. Nevertheless, it remains a trace and to the extent that its potential remains, it remains relevant for translation.

If Derrida's contribution to translation theory is to have any significance for translation practice, the impact of the trace has to be determined - the impact of the spatial and temporal dimensions contained in différance. The key to an application of Derrida's theory has to be sought in the process rather than in the product of translation, and this process has to move beyond a hierarchical opposition of "original" and translation.

Deconstruction radically changes this hierarchy by posing a number of questions that subvert conventional theories. Questioning the primacy of the "original" on the one hand, and more specifically the separate existence of "original" and translation on the other, changes the face of translation entirely, since the "original" and its translation are now regarded to be in a symbiotic relationship. In this regard, Gentzler (1993:146-7) calls attention to Derrida's view that

... what does exist, are different chains of signification including the 'original' and its translations in a symbiotic relationship - mutually supplementing each other, defining and redefining a phantasm of sameness, which has never existed nor will exist as something fixed, graspable, known, or understood. This phantasm, produced by a desire for some essence or unity, represses the possibility that whatever may be there is always in motion, in flux, 'at play', escaping in the very process of trying to define it, talk about it, or make it present.

Ironically, although Pym (1999) questions the usefulness of deconstruction for translation practice, Derrida's "phantasm of sameness" is not that far removed from Pym's (2000) identification of the gap between equivalence as "necessary and functional illusion" and linguistic equivalence. However, Pym regards this illusion as something that the translator has to negotiate and produce for the translation user, whereas Derrida could be seen to regard the phantasm as a product of the desire for unity which merely represses the elusive nature of the trace. Therefore, Pym's more functionalist approach can benefit substantially from a recognition and awareness of the operation of différance. 
In terms of the role of the "original", Bannet (1993:586) expresses the opinion that the translation must pay its debt to the "original", not only by taking its directives from the "original", but also by being a moment in the growth of the "original". Bannet then states that

... this does not mean that original and translation resemble each other or that the translation may not depart from the original, for the translation has only to touch on the original at a few fugitive and 'infinitely small points of sense' ... the translation adds to the original by freeing itself from the original and taking its own course (Bannet, 1993:586).

This refers to Benjamin's notion that a translation touches the original at an infinitely small point of meaning (Benjamin, 1992:81). However, Derrida (1985a:189) reacts to Benjamin's statement with the questions: "What can an infinitely small point of meaning be? What is the measure to evaluate it?" According to Derrida (1985a: 188):

If the translator neither restitutes nor copies an original, it is because the original lives on and transforms itself. The translation will truly be a moment in the growth of the original, which will complete itself in enlarging itself ... And if the original calls for a complement, it is because at the origin it was not there without fault, full, complete, total, identical to itself.

A logical result of the shift from metaphysical and fixed meaning to gaps and traces that cannot be named and therefore silenced or contained, is that the text is "created anew in every reading and no ownership can be declared" (Koskinen, 1994:448). This dethrones the author and renders the hierarchical opposition between source and target text, or "original" and translation, obsolete. If we accept this view of texts, the Renaissance metaphor of translation as footprint of the "original" (Koskinen, 1994:449) can also be revised substantially.

The very act of translation (re)activates the play of traces and by definition creates further plays in relation to the past-become-future through the present, but never in the present, of translation. Therein lies untranslatability in translatability - untranslatability because there is no fixed meaning to begin with and because it is also impossible to transform the différance from one system into another in fixed form. Yet this also contains translatability and the life of translation as process of trace and différance. The very untranslatability provides the tension which makes translation ne- 
cessary as curative process (see Bannet, 1993) - always approaching the potential of the unattainable.

This point of view changes the hierarchical difference between "original" and translation in that, although the translation issues forth from the "original", it does so because the "original" is indebted to the translation for its survival. The translation is therefore not a footprint left by the "original", but a different set of footprints with a similar relation to past, present and future - in other words different from and at the same time similar to the "original" in that it has the same impulse. According to Venuti (1992:7), the poststructuralist concept of textuality compromises the originality of the foreign text in such a way that "neither the foreign text nor the translation is an original semantic unity; both are derivative and heterogeneous". In neither text can the "meaning" be final, for each reading is part of the process of creation that postpones or defers meaning in its creation of another set of gaps and traces.

In the words of Koskinen (1994:450),

translation includes the idea of repetition, but just as signs when repeated are never similar [and therefore change or are modified with every reading], translations can never be identical replicas. Différance takes part in every repetition. Translation is not the same text as the source text, but it is not a different text either. It deconstructs the opposition between difference and sameness.

Inevitably, this deconstruction raises questions about translatability. If signs do not even remain the same in repetition and in intralingual transformations, how can translation begin to claim to be able to name? How can the very notion of différance not result in untranslatability?

\subsection{Translation and the unnameable, untranslatable}

A text lives only if it lives on, and it lives on only if it is at once translatable and untranslatable ... Totally translatable, it disappears as a text, as writing, as a body of language. Totally untranslatable, even within what is believed to be one language, it dies immediately (Derrida, 1979:102).

As a matter of fact, I don't believe that anything can ever be untranslatable - or, moreover, translatable (Derrida, 2001:178).

When Derrida states that nothing is untranslatable and also that nothing is translatable, he refers to a concept of translation based on 
"the condition of a certain economy that relates the translatable to the untranslatable, not as the same to the other, but as same to same or other to other" (Derrida, 2001:178). This economy further signifies both property (in the sense of what is proper or appropriate) and quantity (in other words calculable quantity). A relevant translation, according to Derrida (2001:179), is therefore "a translation whose economy, in these two senses, is the best possible, the most appropriating and the most appropriate possible".

He explains this further as an "economy of in-betweenness" in which "any given translation, whether the best or the worst, actually stands between the two, between absolute relevance, the most appropriate, adequate, univocal transparency, and the most aberrant and opaque irrelevance" (Derrida, 2001:179). What Derrida's "economy" therefore seems to signify, is that anything is translatable if the translator is not limited in terms of quantity, ${ }^{10}$ but that the law of "quantity" renders it impossible to translate fully in terms of the law of "property". In translation an economy is therefore essential and will always be situated somewhere between absolute relevance and absolute irrelevance.

If we leave Derrida at this point of the argument, it would seem that he does indeed pronounce translation, in the conventional use of the term, to be impossible. Yet, this does not mean that his ideas are only meaningful in the ambit of (philosophical) interpretation and useless for translation practice and application, as Pym argues in his Doubts about deconstruction as a general theory of translation (1999). Untranslatability in Derrida's use of the term does not imply that translators should not translate. It simply implies that it is impossible to produce the plurality of the source text in a translation while obeying the law of quantity.

As mentioned in the introduction, deconstruction upsets traditional views of translation by removing equivalence from the skopos or purpose of translation. From the perspective of deconstruction, it is no longer possible to reduce the aim of translation to creating a target text that is equivalent to the source text (regardless of which aspects are considered important in terms of equivalence). Rather, translation becomes more focused on the complex set of relations

10 This aspect is illustrated in his article, "What is a 'relevant' translation?" (Derrida, 2001), where he provides an elaborate and eloquent justification for his choice of the French verb "relève" to translate the English verb "seasons" in The Merchant of Venice. 
between the two texts, without awarding a primary status to either and without claiming the ability to gauge the exact meaning beneath the surface structure of the source text or to encode it in the surface structure of the target text (cf. Nida, 1964). On the contrary, what becomes important also includes everything that is not evidenced in the surface structure of a text, which in turn includes all aspects that are activated in the writing or rewriting of the text (therefore also in its reading and translation).

Commenting on the consequence of the notion of untranslatability for translation, Bannet (1993:580-1) states:
After De Man, we might be tempted to stop here: the translator, per definition, fails. The translator can never do what the original text did. Any translation is always second in relation to the original ... But after Derrida, it becomes apparent that ... the failure of translation and the wandering, errance, and exile of language envelop two possibilities, one lethal, the other curative.

In Bannet's view, De Man develops the lethal possibility and Derrida the curative in their respective treatments of Benjamin's Die Aufgabe des Übersetzers (1972; see Benjamin 1992). De Man interprets Benjamin "lethally", as saying that the task and the duty of the translator are to give up and that translations do not relate to the life of the "original", but to its death. This results in a view that "translation is the resistance to translation; and the wandering, the erring of metaphors, the resistance to metaphor" (Bannet, 1993:582584). In contrast, "Derrida explores the curative possibility enveloped in the wandering, errance, and exile of language and in the inevitable failure of translation". Therefore, according to Bannet, Derrida interprets Benjamin as saying that "the duty of the translator is the duty of an inheritor, the debt that of a survivor, and the responsibility that of an agent of survival" who has to ensure the survival and living on of the "original"11 (Bannet, 1993:585). Indeed, Derrida (1985a:179) states that "[t]here is life at the moment when 'sur-vival' (spirit, history, works) exceeds biological life and death". This is precisely where the curative force of différance lies. Because

11 Referring to the title of Benjamin's essay, Derrida (1985a:175) remarks that it "also says, from its first word, the task (Aufgabe), the mission to which one is destined (always by the other), the commitment, the duty, the debt, the responsibility. Already at stake is a law, an injunction for which the translator has to be responsible. He must also acquit himself, and of something that implies perhaps a fault, a fall, an error and perhaps a crime." 
différance implies that meaning is always postponed and can never be present, the potential lives on in the trace, also constituted in translation. And traces, according to Davis (2001:30), "are always repeatable or iterable".

According to Bannet (1993:585), in Derrida's translation of Benjamin, "the relation between original and translation is based not on resemblance, but on difference. The alliance ... between original and translation ... depends on the difference of two parties or two texts that can only be joined through their differences". These differences complete them and in their completion they are both changed.

Untranslatability is therefore intimately connected to the cont(r)act between the translation and the "original", a contract through the contact between two texts that are always becoming in a symbiotic relationship of rewriting. This relationship to a large extent depends on the creative power contained in the play of the trace. Translation therefore no longer fixes the same meaning, but creates new avenues for further difference.

Although there is a common misconception that Derrida claims complete freeplay and undecidability in language, it should be clear from the preceding that this is not the case. According to Davis (2001:30), Derrida does not claim that there can be no stability of meaning". In fact, "stability and instability ... are mutually constitutive necessities" (Davis, 2001:32). Davis elaborates on the concept of stability, stressing that, although it gives us access to texts due to historical repetition, institutionalisation etcetera, it is also limited because there is always difference at the origin, each repetition is different from all the others, and neither a text's author nor its enactment in one context can fully determine its repetition in another context (Davis, 2001:32).

To return to Derrida's statement cited at the beginning of this paragraph, that he does not believe that "anything can ever be untranslatable - or, moreover, translatable" (Derrida, 2001:178), we could say the following: Nothing can ever be untranslatable because every sign is repeatable, and nothing can be translatable because it can only be repeated in a different context which, according to Davis (2001:34), causes the possibilities for its meaning to remain open. 


\section{Conclusion: translating outwards}

Translation is writing; that is, it is not translation only in the sense of transcription. It is a productive writing called forth by the original text. (Derrida, 1985b:153.)

Derrida's contribution to translation theory goes beyond the obvious implications of différance. To a significant extent, Derrida could be said to reclaim the productive potential of translation that emerges from his emphasis on the play of the trace. Calling translation "a productive writing" imbues it with the power to activate hidden traces, ensuring the survival of the "original" at the same time as the translation issues from it.

However, Derrida contrasts the necessity for translation (contained in the "calling forth" of the translation by the "original") to the desire for an intact kernel. In this vein he says that "the desire or the phantasm of the intact kernel is irreducible - despite the fact that there is no intact kernel" (Derrida, 1985a:115). Because there is no intact kernel, this desire can never be satisfied, yet it remains and produces the tension that makes translation productive. The unattainable nature of translation as well as the opposing necessity for translation therefore produces a vortex that ensures the life of the "original" in its transformation by the translation - a process that necessarily proceeds outward.

Only by passing through the trial of undecidability can the decisions on which translation is premised be made. In the words of Davis (2001:90), "since translations can never perfectly transport an 'original' (there being no fully determined original in the first place), they require decisions, in the strong sense of that word".

With regard to the theory of translation, deconstruction forces us to break with conventional logocentric approaches to translation that are necessarily directed inward, towards the source text and some metaphysical notion of meaning. Instead it becomes imperative to direct our thinking and translation theory as well as practice outward, in the spirit of Cicero's notions of explicare, reddere, and exprimere imitando, which are identified by Robinson (1997:184-185) as providing a decidedly outward impetus. Explicare, for example, "is to explicate, of course, to expound, to interpret, but specifically in the conflicted sense of both 'ordering' and 'setting free', both 'making plain' and 'spreading out'” (Robinson, 1997:186). Even in taking us back to Cicero, and in deconstructing his terms, Robinson therefore confirms the necessary condition of opposition, difference and 
tension contained in translation. For, as Derrida (1992:258) suggests, it is specifically that which is untranslatable which calls for translation; and, "a translation never succeeds in the pure and absolute sense of the term. Rather, a translation succeeds in promising success, in promising reconciliation" (Derrida, 1985b: 123).

Therefore, différance becomes not an obstacle or barrier to translation, but specifically that which, in making something untranslatable, creates the need for translation. For just as conflict is a condition for change, the fact that a text is at once translatable and untranslatable allows for its survival - because the terms are not binary oppositions but become conditions for the existence of each other. Nothing can be wholly untranslatable or wholly translatable. The translatability is premised on what is untranslatable and vice versa. It is in the gaps arising from this conflict that the traces that generate meaning emerge - perhaps not a closed meaning, but the possibility and promise of as well as a yearning for meaning. Just as untranslatability becomes a condition for translatability, 'mistranslation' is a condition for translation.

This dynamic quality of Derrida's thoughts on translation makes it possible to project a theory of translation that invites translators and readers alike to engage in the play of the trace. Although such a theory is concerned with the word and the love for the word, it also leaves "the other body intact but not without causing the other to appear" (Derrida, 2001:175).

\section{List of references}

Bannet, E.T. 1993. The scene of translation: After Jakobson, Benjamin, De Man, and Derrida. New Literary History, 24:577-595, Summer.

Begam, R. 1992. Splitting the différance: Beckett, Derrida and the unnamable. Modern Fiction Studies, 38(4):873-892, Winter.

Benjamin, W. 1992. The task of the translator. Trans. Harry Zohn. In: Schulte, R. \& Biguenet, J. (eds.) Theories of translation: An anthology of essays from Dryden to Derrida. Chicago : University of Chicago Press. p. 71-82.

Berman, A. 2000. Translation and the trials of the foreign. In: Venuti, L. (ed.) The translation studies reader. London : Routledge. p. 284-297.

Cohen, L. 1992. The Future. London : Sony.

Clarkson, C. 2003. "By any other name": Kripke, Derrida and an ethics of naming. Journal of Literary Studies, 32:35-47.

Davis, K. 2001. Deconstruction and translation. Manchester : St. Jerome.

Derrida, J. 1974. Of grammatology. Trans. Gayatri Chakravorty Spivak. London : Johns Hopkins University Press. 
Derrida, J. 1979. "Living on" and "Border Lines". Trans. James Hulbert. In: Bloom, H., De Man, P., Derrida, J., Hartman, G. \& Miller, J.H. Deconstruction and criticism. New York : Seabury Press. p. 75-176.

Derrida, J. 1981. Positions. Trans. Alan Bass. Chicago : University of Chicago Press.

Derrida, J. 1982. Margins of philosophy. Trans. Alan Bass. Brighton : Harvester.

Derrida, J. 1985a. Des tours de Babel. Trans. Joseph F. Graham. In: Graham, J.F. (ed.) Difference in translation. Ithaca : Cornell University Press. p. 209-248.

Derrida, J. 1985b. The ear of the other: Otobiography, transference, translation. Trans. Peggy Kamuf. New York : Schocken.

Derrida, J. 1992. Ulysses gramophone: Hear Say Yes in Joyce. Trans. Tina Kendall. In: Attridge, D. (ed.) Jacques Derrida: Acts of literature. New York : Routledge. p. 253-309.

Derrida, J. 2001. What is a "relevant" translation? Critical Inquiry, 27(2):174200, Winter.

Gentzler, E. 1993. Contemporary translation theories. London : Routledge.

Jakobson, R. 2000. On linguistic aspects of translation. In: Venuti, L. (ed.) The translation studies reader. London : Routledge. p. 113-118.

Koskinen, K. 1994. (Mis)translating the untranslatable: The impact of deconstruction and post-structuralism on translation theory. Meta: Journal des Traducteurs/Translators' Journal, 39(3):446-452.

Lewis, P.E. 2000. The measure of translation effects. In: Venuti, L. (ed.) The translation studies reader. London : Routledge. p. 264-283.

Nida, E. 1964. Towards a science of translating. Leiden : Brill.

Pym, A. 1999. Doubts about deconstruction as a general theory of translation. [Web:] http://www.fut.es/ apym/on-line/decon.html [Date of access: 28 March 2001].

Pym, A. 2000. European translation studies, une science qui dérange, and why equivalence needn't be a dirty word. [Web:] http://www.fut.es/ apym/ deranger.html [Date of access: 25 January 2001].

Robinson, D. 1997. What is translation? Centrifugal theories, critical interventions. Kent : Kent State University Press.

Van den Broeck, R. 1988. Translation theory after deconstruction. Linguistica Antverpiensia, 22:266-88.

Venuti, L. (ed.) 1992. Rethinking translation: Discourse, subjectivity, ideology. London : Routledge.

Venuti. L. (ed.) 2000. The translation studies reader. London : Routledge.

Venuti, L. 2001. Introduction. Critical Inquiry, 27(2):169-173, Winter.

Vermeer, H.J. 2000. Skopos and commission in translational action. Trans. Andrew Chesterman. In: Venuti, L. (ed.) The translation studies reader. London : Routledge. p. 221-232. 


\section{Key concepts:}

deconstruction

différance

translation

play of the trace

Kernbegrippe:

dekonstruksie

spel van die spoor

différance

vertaling 
